"The impact of marketing agility on crisis management stages at five and fourstar hotels in Jordan"

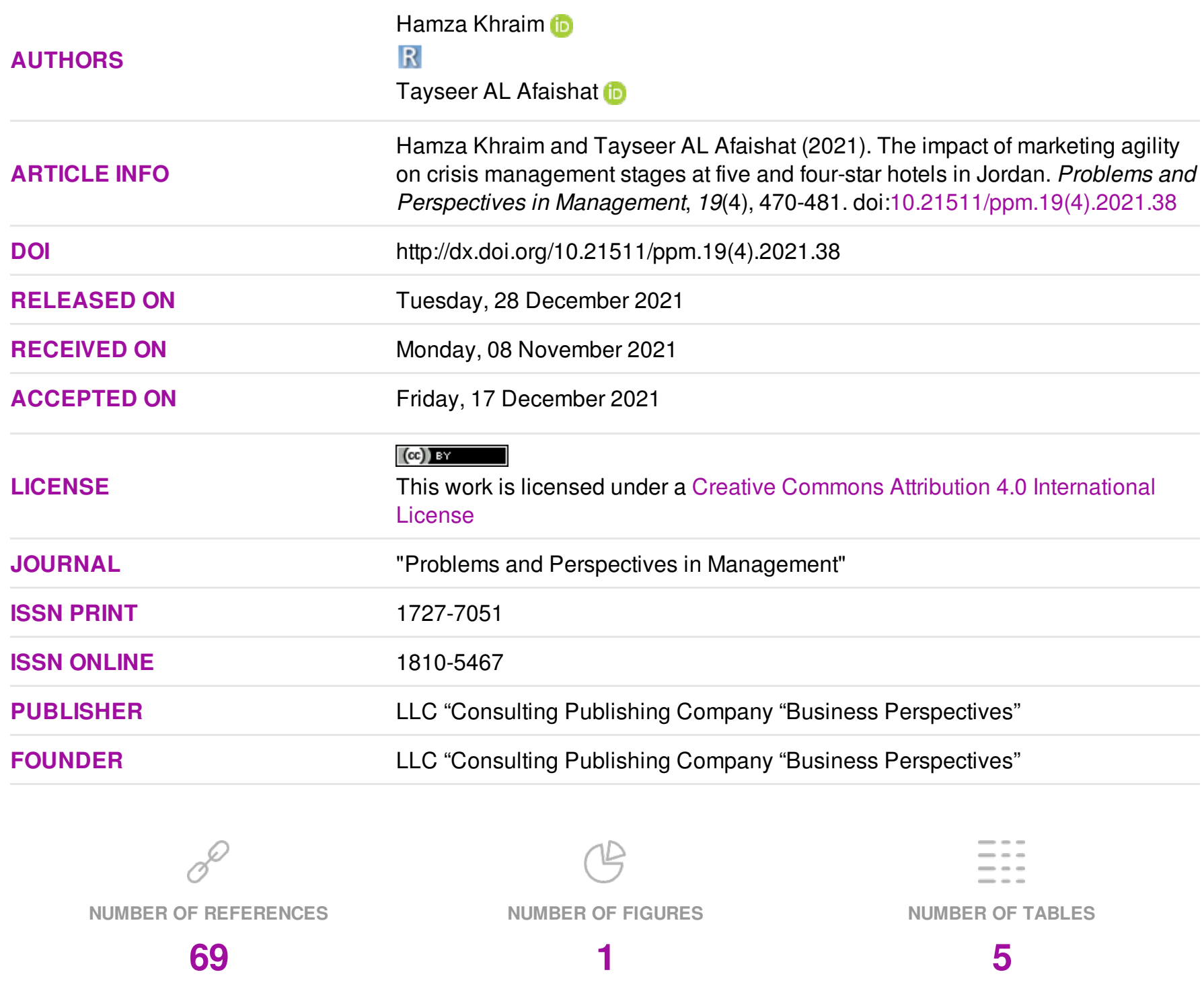

(C) The author(s) 2022. This publication is an open access article. 


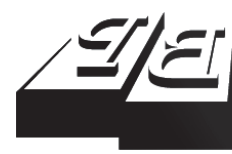

\section{BUSINESS PERSPECTIVES}

LLC "CPC "Business Perspectives" Hryhorii Skovoroda lane, 10, Sumy, 40022, Ukraine www.businessperspectives.org
Received on: $8^{\text {th }}$ of November, 2021 Accepted on: $17^{\text {th }}$ of December, 2021 Published on: $28^{\text {th }}$ of December, 2021

(c) Hamza Khraim, Tayseer AL Afaishat, 2021

Hamza Khraim, Ph.D., Associate Professor, Business Administration Department, Faculty of Business, Amman Arab University, Jordan. (Corresponding author)

Tayseer AL Afaishat, Ph.D., Assistant Professor, Business Administration Department, Faculty of Business, Amman Arab University, Jordan.
This is an Open Access article, distributed under the terms of the Creative Commons Attribution 4.0 International license, which permits unrestricted re-use, distribution, and reproduction in any medium, provided the original work is properly cited.

Conflict of interest statement: Author(s) reported no conflict of interest

Hamza Khraim (Jordan), Tayseer AL Afaishat (Jordan)

\title{
THE IMPACT OF MARKETING AGILITY ON CRISIS MANAGEMENT STAGES AT FIVE AND FOUR-STAR HOTELS IN JORDAN
}

\begin{abstract}
This paper aims to examine the impact of marketing agility on decision-making during crisis management stages in five-star and four-star hotels in Jordan. The study included 71 top management staff members from Jordan's five- and four-star hotels. A questionnaire was designed and utilized to collect the data on marketing agility and crisis management at four and five-star hotels in Jordan. A total of 213 questionnaires were distributed, and 187 useable responses were returned, which resulted in an 86\% response rate. Results show that marketing agility plays a significant role in decisionmaking during crisis management stages. The analysis revealed that marketing agility affected the five stages of crisis management with mixed levels. The findings show that accessibility, decisiveness, swiftness, and flexibility have an immense impact on crisis management stages, while the alertness dimension result shows a weak impact on crisis management stages except for containment. Hotel managers are recommended to emphasize enhancing coordination and integration internally with different managerial levels and units and with external partners to boost information exchange. In addition, it will help promote learning orientation amongst hotel staff to handle the fast-changing environment.
\end{abstract}

\section{Keywords}

JEL Classification

\section{INTRODUCTION}

The COVID-19 pandemic's global spread continues to cause chaos in all sectors, particularly in the travel, tourism, and hospitality industries, which depend heavily on the flux of tourists. According to Sorrells (2020), the global lockdown affected all tourism activities related to travel, hospitality, and air transportation. Many countries tend to close their borders and suspend flights from highly infected countries to control the pandemic's spread and protect people from new waves of viruses, and Jordan was no exception. The Jordanian government took many measures to suppress the spread of the COVID-19 pandemic, including the closure of many activities, especially in the service sectors that depend on people's social contact and gatherings to preserve social distance and protect people. The suspension of international flights and the imposition of a travel ban on tourists coming from other countries caused many tourists to cancel ticket and hotel reservations. The tourism industry saw a sharp drop in revenue and a drop in hotel demand of 85 percent (Raouf et al., 2020). These necessary measures hurt the growth of all economic sectors in Jordan, especially the tourism and hospitality industries, which depend mainly on international travelers. These unprecedented circumstances place 
hotel management under pressure to keep up services and operations as usual despite the economic crisis. Hotel management is required to respond to this odd situation swiftly and prudently. In the past two years, the world has suffered an economic downturn and slow growth caused by the COVID-19 pandemic, and the hospitality sector was among the most affected sectors. The hotel industry is facing the most pressure it has ever encountered, and hotels are trying to survive this crisis.

\section{LITERATURE REVIEW}

The COVID-19 pandemic created new challenges for managers. Boudet et al. (2020) suggest that marketing models should be modified accordingly. Moorman (2020) proposed that organizations need to apply flexible models and asserted that "marketing needs to be agile". Homburg and Pflesser (2020) viewed marketing agility as the prime priority for producing marketing excellence. Rachmawati et al. (2019) point out that agility can assist the company in increasing the abilities and capabilities to act proactively in response to unpredicted external environmental changes.

\subsection{Development and definition of marketing agility}

The appearance of agile thinking can be traced back to many academic fields, such as manufacturing, sociology, and education (Prange \& Heracleous, 2018). The inauguration of the agile concept appeared after the declaration of "The Agile Manifesto" in 2001, and it was a moderately limited concept that focused on more precisely dealing with the software development community. The growth of the agile concept was very dynamic and evolved in an accelerated style to encompass more comprehensive and progressive realms across all types of businesses and industries, such as manufacturing, supply chain, marketing, human resources, and innovation. Dierdorf (2019) and Meyer (2016) contributed to the diverse aspects of agile by adopting the concept to reflect their area of interest. Currently, "agile" is one of the most famous tags in the business community (The Economist, 2018). Ewel (2011) announced the Agile Marketing Manifesto, which contained the Agile Marketing principles and values based on a faster pace, customer engagement, and coordination and was intended to enable the company to deal with market changes in a flexible, efficient, and effective manner. The agile marketing approach's supreme purpose is to enable and support marketing functions to react and adjust swiftly and cost-efficiently to market fluctuations (Accardi-Petersen, 2011). This new approach depends on the effectual synthesis of resources, including people, technology, and management, to deliver more practical marketing solutions, especially in increasingly dynamic and turbulent environments (Inversini et al., 2014). Agile practices are a significant instrument that improves work quality by enhancing innovation, maximizing productivity, handling and modifying priorities according to feedback in more responsive and efficient processes, and achieving better results through enhanced comprehensive collaboration among units, teams, and company objectives (Accardi-Petersen, 2011; Fryrear, 2018; Ewel, 2011; Millar et al., 2018). Agility is defined as reshaping and maneuverability of options swiftly in response to inconstant requirements and circumstances in the business context to harvest potential advantages (Kartik et al., 2020; Nemkova, 2017; Gligor et al., 2015; Li et al., 2009; Agarwal et al., 2007). Whereas Homburg and Pflesser (2020, p. 10) conceptualize it as a firm's strategic means for attaining growth activities by the marketing company and its affiliates through simplified arrangements and processes, swift decision making, and trial and error learning.

\subsection{Marketing agility benefits and measurement}

As far as marketing is concerned, Golgeci and Gligor (2017) and Zhou et al. (2018) found a direct positive connection between marketing performance and agility. Matthyssens et al. (2005) found that agility plays a vital tool in creating a successful competitive advantage and creating customer value. Tahmasebifard et al. (2017) found that agility provides massive aid in managing market-related changes such as escalating competition, innovative customer requirements, launching new products, and accelerated technological development. Golgeci and Gligor (2017) asserted that marketing 
agility will empower the organization to develop demand by promptly modifying strategies, tactics, and operations according to environmental fluctuations. Furthermore, employing marketing agility is considered a mechanism for "embracing change" that makes the organization more responsive to market needs and enables the organization to master innovation, therefore allowing it to succeed (Osei et al., 2019; Tahmasebifard et al., 2017; O'Keeffe et al., 2016). Finally, Fryrear (2018) surveyed 693 marketers in the United States; the results showed that $36.7 \%$ already embraced agile methods and used them among marketing units. The survey results reported that agility has a positive impact on business performance. Lack of senior management support will reduce agility effectiveness and efficiency and eradicate at least 50\% of the value of the agile marketing approach (Ewel, 2011). Moi (2019), Gligor et al. (2013), and Li et al. (2009) support the multidimensional structure of this concept. The heterogeneity and cross-disciplinary nature of agility have yielded a valuable multidimensional conceptualization. For example, Kartik et al. (2020) asserted that the marketing agility concept is a multidimensional construct. Gligor et al. (2013) designed a measurement scale of agility that examines the multidimensionality of the concept. They identify five dimensions of agility, including alertness, accessibility, decisiveness, swiftness, and flexibility. Following the mainstream research support of the multidimensional structure of marketing agility, this study uses the dimensions generated by Gligor et al. (2013) and modifies them to fit the current analysis. The enclosed dimensions are alertness, accessibility, decisiveness, swiftness, and flexibility.

\subsection{Crisis management in the hotel industry}

The Institute for Crisis Management - ICM (n.d.) defined crisis as an issue, problem, or disorder which triggers negative stakeholder responses that can influence the organization's reputation, business, and financial strength. Bundy et al. (2017) defined a crisis as an event perceived by managers and stakeholders as highly salient, unexpected, and potentially disruptive and can threaten organizational goals. ICM further elucidated that mismanagement of a crisis can drive up costs and complicate the responsibilities of organizations.
Ritchie and Jiang (2019) cited that crisis results from internal organizational failure to act wisely to deal with external events that happen over which the organization has no control, such as in the case of a disaster. Current estimates show that the tourism industry expects to lose more than 2.1 trillion US dollars in revenue (WTTC, n.d.). To deal with crisis more effectively, the crisis models were developed and divided into four main categories (Kim, 2002; Coombs, 2000; Mitroff \& Pearson, 1993; Pauchant \& Mitroff, 1992). Crisis management is viewed as a series of steps or cyclical processes that consist of pre-crisis, crisis, and post-crisis stages. The pre-crisis stage involves the signal detection of expected crises, crisis preparation, and crisis prevention. The second stage is the crisis stage, and it instigates a trigger incident and consists of two components: crisis recognition and crisis containment. The post-crisis stage consists of two components: recovery and learning (Mitroff et al., 1987; Mitroff et al., 1996; Coombs, 2007). Pearson and Mitroff (1999) suggested a five-stage framework for crisis management: 1) signal detection; 2) preparation/prevention; 3) containment/damage limitation; 4) recovery; and 5) learning. Kim (2002) suggested six types of crisis management activities that should be underway: signal detection, recognition, preparation, prevention, containment/recovery, and learning. Moreover, Ritchie (2004) introduced a new strategic approach to crisis management deemed to be more "holistic", presented in three stages: 1) proactive pre-crisis planning, 2) strategy implementation, and 3) evaluation and feedback. Table 1 shows a framework for crisis management stages suggested by different authors. Many previous studies utilized Mitroff and Pearson's (1993) instrument, such as Jabouri (2011), Alkhawlani et al. (2016), Chowdhury and Quaddus (2016), Saeed (2020), and Alzoubi and Jaaffar (2020). This instrument consists of twenty-nine items that measure the five-stage dimensions of crisis management. Furthermore, Crandall et al. (2014) asserted that the five-stage framework proposed by Pearson and Mitroff (1993) provides a more comprehensive approach to understanding crisis stages than the four-stage framework models.

Endemics, epidemics, and pandemics have catastrophic consequences for the travel and tourism sector. Guevara (2020) asserted that the travel and 
Table 1. Frameworks for crisis management stages

Source: Authors' elaboration based on Crandall et al. (2014).

\begin{tabular}{|c|c|c|c|c|c|c|c|}
\hline Stage & $\begin{array}{c}\text { 3-Stage } \\
\text { Framework }\end{array}$ & $\begin{array}{c}\text { 3-Stage } \\
\text { Framework }\end{array}$ & $\begin{array}{c}\text { 4-Stage } \\
\text { Framework }\end{array}$ & $\begin{array}{c}\text { 4-Stage } \\
\text { Framework }\end{array}$ & $\begin{array}{c}\text { 4-Stage } \\
\text { Framework }\end{array}$ & $\begin{array}{c}\text { 4-Stage } \\
\text { Framework }\end{array}$ & $\begin{array}{c}\text { 5-Stage } \\
\text { Framework }\end{array}$ \\
\hline $\begin{array}{l}\text { 3-Stage } \\
\text { General } \\
\text { Framework }\end{array}$ & Smith (1990) & $\begin{array}{l}\text { Richardson } \\
\text { (1994) }\end{array}$ & Myers (1993) & UNEP (2008) & Fink (1996) & $\begin{array}{l}\text { Crandall et al. } \\
\qquad(2014)\end{array}$ & $\begin{array}{c}\text { Mitroff and } \\
\text { Pearson (1993) }\end{array}$ \\
\hline \multirow{2}{*}{$\begin{array}{l}\text { 1- Before the } \\
\text { Crisis } \\
\text { stage }\end{array}$} & \multirow{2}{*}{$\begin{array}{c}\text { Crisis of } \\
\text { management }\end{array}$} & \multirow{2}{*}{$\begin{array}{c}\text { Precrisis/ } \\
\text { disaster phase }\end{array}$} & \multirow{2}{*}{$\begin{array}{c}\text { Normal } \\
\text { operations }\end{array}$} & Prevention & \multirow{2}{*}{$\begin{array}{l}\text { Prodromal } \\
\text { crisis stage }\end{array}$} & $\begin{array}{c}\text { Landscape } \\
\text { survey }\end{array}$ & $\begin{array}{c}\text { Signal } \\
\text { detection }\end{array}$ \\
\hline & & & & Preparedness & & $\begin{array}{l}\text { Strategic } \\
\text { planning }\end{array}$ & $\begin{array}{l}\text { Preparation/ } \\
\text { Prevention }\end{array}$ \\
\hline \multirow{2}{*}{$\begin{array}{l}\text { 2-During the } \\
\text { Crisis } \\
\text { stage }\end{array}$} & \multirow{2}{*}{$\begin{array}{l}\text { Operational } \\
\text { crisis }\end{array}$} & \multirow{2}{*}{$\begin{array}{l}\text { Crisis impact/ } \\
\text { rescue phase }\end{array}$} & $\begin{array}{c}\text { Emergency } \\
\text { response }\end{array}$ & \multirow{2}{*}{ Response } & $\begin{array}{c}\text { Acute crisis } \\
\text { stage }\end{array}$ & \multirow{4}{*}{$\begin{array}{c}\text { Crisis } \\
\text { management } \\
\text { organizational } \\
\text { learning }\end{array}$} & \multirow{2}{*}{$\begin{array}{c}\text { Containment/ } \\
\text { Damage } \\
\text { limitation }\end{array}$} \\
\hline & & & $\begin{array}{l}\text { Interim } \\
\text { Processing }\end{array}$ & & $\begin{array}{c}\text { Chronic crisis } \\
\text { stage }\end{array}$ & & \\
\hline \multirow{2}{*}{$\begin{array}{l}\text { 3-After the } \\
\text { Crisis } \\
\text { stage }\end{array}$} & \multirow{2}{*}{$\begin{array}{c}\text { Crisis of } \\
\text { legitimating }\end{array}$} & \multirow{2}{*}{$\begin{array}{c}\text { Recovery/ } \\
\text { demise phase }\end{array}$} & \multirow[b]{2}{*}{ Restoration } & \multirow[b]{2}{*}{ Recovery } & \multirow{2}{*}{$\begin{array}{c}\text { Crisis } \\
\text { Resolution } \\
\text { stage }\end{array}$} & & Recovery \\
\hline & & & & & & & Learning \\
\hline
\end{tabular}

tourism sector is already facing collapse and is in a fight for survival. Hotels are primarily vulnerable to declining tourism and travel, along with a slowdown in economic movement (Hoisington, 2020). Hotel occupancy rates have fallen as events across the globe continue to be canceled or suspended, and the COVID-19 pandemic has caused critical setbacks for hoteliers worldwide (Jiang \& Wen, 2020). Hotels in Jordan also suffered severely from the COVID-19 pandemic lockdown, and there was a drop in demand for hotels by 85 percent (Raouf et al., 2020). This situation encourages hoteliers to act swiftly and take action to face several hurdles induced by crises. Concerning the hotel industry, few studies have been devoted to investigating crises from a strategic point of view (Varelas \& Apostolopoulo, 2020). Based on the literature review, the study proposes the theoretical model (Figure 1).

\section{AIMS AND HYPOTHESES}

This paper aims to implement the agility concept in a Jordanian marketing context. Furthermore, most articles are qualitative, theoretical, or ap- plied to a single-case study (Moi, 2019; Osei et al., 2019). This study aims to overcome those shortcomings and provide empirical-quantitative findings that make it easier to understand the impact of marketing agility on crisis management. Based on the theoretical literature review, the following hypotheses are proposed:

H1: Marketing agility has a significant positive impact on the pre-crisis stage (signal detection).

H2: $\quad$ Marketing agility has a significant positive impact on the pre-crisis stage (preparation and prevention).

H3: Marketing agility has a significant positive impact on the pre-crisis stage (containment, damage limitation).

H4: Marketing agility has a significant positive impact on the post-crisis stage (recovery).

H5: Marketing agility has a significant positive impact on the pre-crisis stage (learning).

\section{CRISIS MANAGEMENT STAGES}

1. Signal detection

2. Preparation/prevention

- Alertness

- Decisiveness

- Swiftness

- Flexibility
3. Containment (damage limitation)

4. Recovery

5. Learning

Figure 1. Theoretical framework 


\section{METHODS}

\subsection{Data collection}

The study uses the quantitative approach by designing and utilizing a structured questionnaire that contains relevant questions about marketing agility and the crisis management stage. To answer the research question, the questionnaire was distributed to five-star and four-star hotels in Jordan. Marketing agility is measured with seventeen items (Gligor et al., 2013; Vinodh, 2010; Tachizawa \& Gimenez, 2010; Heimicke et al., 2021) for crisis management, 29 items were adapted from Alkhawlani et al. (2016), Mitroff and Pearson (1993) and Jabouri (2011). Some items were slightly reconstructed to suit the context of the study. To measure the items on the marketing agility and crisis management stages, a five-point
Likert-type scale was used, with 1 = strongly disagree and $5=$ strongly agree. Five and four-star hotels are deemed to have more resources and education and possess advanced knowledge and experience that enable them to deal with the crisis management process (Karam, 2018). Consequently, the study population consists of five-star and fourstar hotels in Jordan. According to the Ministry of Tourism and Antiques (2019), the total number of hotels is 71, as shown in Table 2. Bilić et al. (2017) note that crisis management practices are the responsibility of upper-level management staff, and all questions or surveys should be directed to those managers. Accordingly, the unit of analysis was general managers, assistants to general managers, and marketing managers. About 198 questionnaires were sent by email, and only 15 questionnaires were submitted by hand as requested. The process took approximately two weeks to

Table 2. Number of five and four-star hotels in main cities in Jordan 2019

Source: Ministry of Tourism and Antiques (2019).

\begin{tabular}{l|c|c|c|c|c}
\hline \multicolumn{1}{c}{ Hotel category } & Amman & Petra & Aqaba & Dead Sea & Total \\
\hline Five-star & 18 & 5 & 7 & 3 & 7 \\
\hdashline Four-star & 25 & 3 & 3 & 3 & 3 \\
Total & 43 & 8 & 10 & 10 & 71 \\
\hline
\end{tabular}

Table 3. Demographic profile

\begin{tabular}{|c|c|c|}
\hline Respondents Demographics & Frequency & Percentage \\
\hline \multicolumn{3}{|c|}{ Gender } \\
\hline Male & 116 & 62.0 \\
\hline Female & 71 & 38.0 \\
\hline Total & 187 & $100 \%$ \\
\hline \multicolumn{3}{|c|}{ Education } \\
\hline Bachelor & 134 & 71.7 \\
\hline Master & 44 & 23.5 \\
\hline Ph.D. & 9 & 4.8 \\
\hline Total & 187 & $100 \%$ \\
\hline \multicolumn{3}{|c|}{ Age } \\
\hline Less than 30 years & 27 & 14.4 \\
\hline $31-40$ years & 77 & 41.2 \\
\hline $41-50$ years & 48 & 25.7 \\
\hline More than 50 years & 35 & 18.7 \\
\hline Total & 187 & $100 \%$ \\
\hline \multicolumn{3}{|c|}{ Position } \\
\hline General Manager & 48 & 25.7 \\
\hline GM Assistant & 109 & 58.3 \\
\hline Marketing Manager & 30 & 16.0 \\
\hline Total & 187 & $100 \%$ \\
\hline \multicolumn{3}{|c|}{ Hotel } \\
\hline 5-star & 131 & 70.1 \\
\hline 4-star & 56 & 29.9 \\
\hline Total & 187 & $100 \%$ \\
\hline
\end{tabular}


complete this survey. Even with the continuous follow-up, 187 usable responses were obtained, which resulted in an $86 \%$ response rate. Table 3 shows the demographic profile of the respondents. $60.2 \%$ of the respondents are males, and $72.5 \%$ hold a bachelor's degree. Regarding age, $41.5 \%$ of the respondents ranged between the ages of 31 and 40. More than half (58.5\%) are GM assistants and $68.4 \%$ work at five-star hotels.

\section{RESULTS}

Factor analysis was used to capture the meaning and purpose of marketing agility and to identify the underlying dimensions. Factor analysis will help align related items into similar factors to enhance examination of their effects on different stages of crisis management. To examine the data appropriateness for conducting factor analysis, the Kaiser-Meyer-Olkin (KMO) was used to measure sampling adequacy. The KMO result was 0.827 and was deemed to have a high value (Hair et al., 2010). Bartlett's test of sphericity shows that variables are unrelated, indicating the correlation matrix is significantly different from the identity matrix (Mazzocchi, 2008). Sphericity resulted in a significant $(\beta=.001)$ result. All these rules for procuring a dimension showed that it was suitable to use factor analysis for summarizing data to realize underlying dimensions that reflect marketing agility (Hair et al., 2010; Mazzocchi, 2008). The current study utilized a principal component analysis using Varimax rotation. This method is used to assign the least number of dimensions that estimate the highest variance in the data (Hair et al., 2010; Malhotra, 2010). Table 4 indicates the loadings for the factors on which the variable loaded the most. As presented, all item loadings were above 60, as described by Hair et al. (2010) and Malhotra (2010). Accordingly, construct validity has been proved since all items have been loaded appropriately with satisfactory loading values. The five-factor structure accounted for $73.62 \%$ of the total variance, and this is considered sufficient compared with the $60 \%$ as prescribed by Malhotra (2010). Cronbach's alpha reliability is performed to test the internal consistency of the retained marketing agility dimensions, and the results were as follows: Alertness: 0.726, Accessibility: 0.908, Decisiveness: 0.878, Swiftness: 0.717, and Flexibility: 0.776. All the dimensions' reliability is above the value of 0.70 or more, which is considered satisfactory (Malhotra, 2010). The Eigenvalues of the five factors were $5.721,2.596,1.852,1.262$, and 1.085 , respectively. To check the internal consistency of the crisis management stages, Cronbach's alpha was used to check the reliability. For the pre-crisis stage of signal detection, Cronbach's alpha was 0.820 , and one question was dropped. While for preparation and prevention, it was 0.728 . In the crisis stage, the reliability result was 0.787 for containment; one question was dropped. For the post-crisis stage, Cronbach's alpha for recovery and learning was 0.741 and 0.728 , respectively, dropping one question from this dimension.

To test the proposed hypotheses, multiple regression analysis was computed for marketing agility dimensions as the independent variables and the pre-crisis stage (signal detection, crisis preparation, and prevention) as the dependent variable. Table 5 shows that marketing agility is a significant predictor of signal detection stage ( $\mathrm{f}=28.07$, $\beta=.01)$. Thus, the study supports $H 1$ : there is a significant positive impact on the pre-crisis stage signal detection. In regression analysis, $R^{2}$ is used to estimate the collective capacity of a construct in terms of variance explained (Hair et al., 2012). The value of $R^{2}$ is 0.437 , which means that the marketing agility dimensions explain the $43.7 \%$ variation in the signal detection stage. As stated in $\mathrm{H} 2$, marketing agility dimensions have a significant positive impact on the pre-crisis stage (crisis preparation and prevention). The regression coefficient results $(f=209.5, \beta=.001)$ back up the proposed significant positive impact and thus confirm $H 2$. The value of $R^{2}$ is 0.853 , which means that the marketing agility dimensions explain $85.3 \%$ of the variations in the preparation stage. It appears that marketing agility dimensions are considered a valuable strategy in dealing with the pre-crisis stage, including signal detection, crisis preparation, and prevention. Multiple regression analysis was used to test marketing agility dimensions as the independent variables and the crisis stage (crisis containment) as the dependent variable. As stated in H3, the marketing agility dimensions have a positive impact on crisis containment. Results show that marketing agility dimensions have a significant impact on crisis containment $(f=304.8, \mathrm{p}<$ $.01)$, therefore, the proposed $H 3$ is confirmed. The 
value of $R^{2}$ is $89.4 \%$, which means that the marketing agility dimensions explain the $89.4 \%$ variation in the containment stage.

Finally, multiple regression analysis was used to test the impact of marketing agility dimensions as the independent variables on the post-crisis stage (recovery and learning) as the dependent variable. According to $H 4$, the marketing agility dimensions have a positive impact on recovery. The regression coefficient results $(f=82.7, \beta=.001)$ support the proposed significant positive effect, confirming the projected $H 4$. The value of $R^{2}$ is 0.696 , which means that the marketing agility dimensions explain the $69.6 \%$ variation in the recovery stage. $H 5$ states that marketing agility dimensions have a positive impact on learning. The regression coefficient $(f=198.8, \mathrm{p}<.001)$ thus confirm the proposed H5. The proposed positive relationship is significantly supported by results in Table 5 : the value of $R^{2}$ is 0.842 ; it means that the marketing agility dimensions explain the $84.2 \%$ variations in the learning stage.
Finally, the results show that marketing agility dimensions have a significant impact on the crisis management stages. It appears that agility marketing is an acceptable assistant for managers through crisis management stages, excluding the alertness dimension.

\section{DISCUSSION}

This paper investigated the impact of those dimensions on crisis management stages in five- and four-star hotels in Jordan during COVID-19. The results confirm the five dimensions used for measuring marketing agility. The analysis revealed that marketing agility affected the five stages of crisis management with mixed levels. The alertness dimension shows no impact on crisis management stages except for containment. This is because no one can predict the occurrence and development of the COVID-19 pandemic crisis. The lockdown of all sectors and the cancellation of travel movements caused chaos for hotel management, which

Table 4. Factor analysis

\begin{tabular}{|c|c|c|c|c|c|c|}
\hline Marketing Agility & F1 & $\mathbf{F 2}$ & F3 & F4 & F5 & $\begin{array}{c}\text { Cronbach's alpha } \\
(\alpha=0.05)\end{array}$ \\
\hline \multicolumn{7}{|c|}{ Alertness (Mean: 3.90) } \\
\hline Alertness 1 & .728 & & & & & \multirow{3}{*}{0.726} \\
\hline Alertness 2 & .794 & & & & & \\
\hline Alertness 3 & .734 & & & & & \\
\hline \multicolumn{7}{|c|}{ Accessibility (Mean: 3.70) } \\
\hline Accessibility 1 & & .799 & & & & \multirow{4}{*}{0.908} \\
\hline Accessibility 2 & & .826 & & & & \\
\hline Accessibility 3 & & .801 & & & & \\
\hline Accessibility 4 & & .789 & & & & \\
\hline \multicolumn{7}{|c|}{ Decisiveness (Mean: 3.65) } \\
\hline Decisiveness 1 & & & .870 & & & \multirow{4}{*}{0.878} \\
\hline Decisiveness 2 & & & .786 & & & \\
\hline Decisiveness 3 & & & .623 & & & \\
\hline Decisiveness 4 & & & .771 & & & \\
\hline \multicolumn{7}{|c|}{ Swiftness (Mean: 3.61) } \\
\hline Swiftness 1 & & & & .698 & & \multirow{3}{*}{0.717} \\
\hline Swiftness 2 & & & & .816 & & \\
\hline Swiftness 3 & & & & .643 & & \\
\hline \multicolumn{7}{|c|}{ Flexibility (Mean: 3.15) } \\
\hline Flexibility 1 & & & & & .754 & \multirow{3}{*}{0.776} \\
\hline Flexibility 2 & & & & & .827 & \\
\hline Flexibility 3 & & & & & .821 & \\
\hline
\end{tabular}

Note: Extraction Method: Principal Component Analysis. Rotation Method: Varimax with Kaiser Normalization. 
Table 5. Regression analysis

\begin{tabular}{|c|c|c|c|c|c|c|c|c|c|c|c|c|c|c|c|}
\hline \multirow{3}{*}{$\begin{array}{c}\text { Agility } \\
\text { Dimensions }\end{array}$} & \multicolumn{3}{|c|}{ Signal Detection } & \multicolumn{3}{|c|}{ Preparation } & \multicolumn{3}{|c|}{ Containment } & \multicolumn{3}{|c|}{ Recovery } & \multicolumn{3}{|c|}{ Learning } \\
\hline & \multicolumn{3}{|c|}{$R^{2}: .437$} & \multicolumn{3}{|c|}{$R^{2}: .853$} & \multicolumn{3}{|c|}{$R^{2}: .894$} & \multicolumn{3}{|c|}{$R^{2}: .696$} & \multicolumn{3}{|c|}{$R^{2}: .842$} \\
\hline & $\mathrm{t}$ & Sig. & $\beta$ & $\mathbf{t}$ & Sig. & $\beta$ & $\mathbf{t}$ & Sig. & $\beta$ & $\mathbf{t}$ & Sig. & $\beta$ & $t$ & Sig. & $\beta$ \\
\hline Alertness & $-.610-$ & .543 & $-.040-$ & $-.480-$ & .632 & $-.012-$ & 12.928 & .000 & .297 & $-.114-$ & .909 & $-.004-$ & $-.228-$ & .820 & $-.007-$ \\
\hline Accessibility & .944 & .500 & .003 & 12.48 & .000 & .288 & 13.645 & .000 & .292 & 2.985 & .016 & .032 & 10.24 & .000 & .000 \\
\hline Decisiveness & 1.823 & .012 & $-.023-$ & 17.34 & .000 & .396 & 14.164 & .000 & .300 & 2.850 & .005 & .091 & $-2.43-$ & .016 & $-.073-$ \\
\hline Swiftness & -2.732 & .007 & $-.173-$ & 2.610 & .022 & $-.026-$ & $-2.221-$ & .028 & $-.049-$ & 16.486 & .000 & .546 & 11.03 & .000 & .345 \\
\hline Flexibility & 11.273 & .000 & .570 & .068 & .946 & .001 & 2.582 & .013 & .010 & -.998 & .320 & $-.026-$ & 20.97 & .000 & .522 \\
\hline F Sig. & 28.072 & .000 & & 209.59 & .000 & & 304.863 & .000 & & 82.726 & .000 & & 198.88 & .000 & \\
\hline
\end{tabular}


created a need to contain the catastrophic consequences of this crisis. Results show the second dimension, accessibility, has an impact on four stages except for the first stage, the signal detection stage. Accessibility and availability of pertinent information internally and externally can facilitate managing crises and reduce their effect on hotel operations. Again, accessibility was not significant at the signal detection stage since such diseases can be extremely hard to detect. The result shows that the third dimension of decisiveness has an impact on all crisis management stages. Top management intervention is needed to make the right and timely decision at all crisis stages to minimize the side effects and accelerate the recovery processes. Similar to decisiveness, results revealed that swiftness also has an impact on all crisis management stages. Acting in a swift style will reduce the time of each stage during the crisis, which helps in rising above competitors in coping with the crisis with velocity. Finally, results show that the flexibility dimension has influenced the three stages, including signal detection, containment, and learning. Overall, the results indicate that marketing agility has less impact in the pre-crisis stage and more impact in the crisis and post-crisis stages.

\section{CONCLUSION}

The study aimed to explore the impact of marketing agility dimensions such as alertness, decisiveness, swiftness, and flexibility on the different crisis management stages that include preparation, containment, signal detection, recovery, and learning in five-star and four-star hotels in Jordan. The main results show that marketing agility impacts crisis management stages, albeit at different magnitudes. In general, the findings indicate that accessibility, decisiveness, swiftness, and flexibility have an immense impact on crisis management stages, while the alertness dimension result shows a weak impact on crisis management stages except for containment. The current study emphasizes the need to improve the alertness dimension to enhance crisis forecasting by managers. The study also underlines the importance of accessibility and readiness of relevant information internally and externally to facilitate decision-making. This information will enable top management to deal swiftly with any changes and take timely decisions. It is important here to highlight that hotel management needs to upgrade and improve its pre-crisis stage dimensions to achieve better results with subsequent stages in managing the crisis.

\section{AUTHOR CONTRIBUTIONS}

Conceptualization: Hamza Khraim.

Data curation: Hamza Khraim.

Formal analysis: Hamza Khraim.

Methodology: Hamza Khraim.

Project administration: Tayseer AL Afaishat.

Resources: Tayseer AL Afaishat.

Software: Tayseer AL Afaishat.

Validation: Tayseer AL Afaishat.

Writing - original draft: Hamza Khraim.

Writing - review \& editing: Tayseer AL Afaishat.

\section{REFERENCES}

1. Accardi-Petersen, M. (2011). Agile Marketing. New York: Apress.

2. Agarwal, A., Shankar, R., \& Tiwari, M. K. (2007). Modeling Agility of Supply Chain. Industrial Marketing Management, 36(4)
443-457. https://doi.org/10.1016/j. indmarman.2005.12.004

3. Alkhawlani, M. A. S., Al Haderi, S. M., bin Bohari, A. M., bin Ahmed, F., \& Rahim, N. A. F. (2016). Charisma Leadership an
Important Determinant for the Crisis Management. International Journal of Business and Social Science, 7(9), 126-136. Retrieved from http://www.ijbssnet.com/ journals/Vol_7_No_9_September_2016/14.pdf 
4. Alzoubi, R. H., \& Jaaffar, A. H. (2020). The mediating effect of crisis management on leadership styles and hotel performance in Jordan. International Journal of Financial Research, 11(4), 384-397. http://dx.doi.org/10.5430/ijfr. v11n4p384

5. Bilić, I., Pivčević, S., \& Čevra, A. (2017). Crisis Management in Hotel Business-Insights from Croatia. Communication Management Review, 2(2), 100118. http://dx.doi.org/10.22522/ cmr20170225

6. Boudet, J., Gordon, J., Gregg, B., Perrey, J., \& Robinson, K. (2020, April 8). How Marketing Leaders Can Both Manage the Coronavirus Crisis and Plan for the Future. McKinsey \& Company. Retrieved from https://www. mckinsey.com/business-functions/ marketing-and-sales/our-insights/ how-marketing-leaders-can-bothmanage-the-coronavirus-crisisand-plan-for-the-future

7. Bundy, J., Pfarrer, M. D., Short, C. E., \& Coombs, W. T. (2017). Crises and Crisis Management: Integration, Interpretation, and Research Development. Journal Management, 43(6), 1661-1692. https://doi. org/10.1177/0149206316680030

8. Chan, C., Nozu, K., \& Cheung, T. (2020). Tourism and natural disaster management process: perception of tourism stakeholders in the case of Kumamoto earthquake in Japan. Current Issues in Tourism, 23(15), 18641885. http://dx.doi.org/10.1080/13 683500.2019.1666809

9. Chowdhury, M. M. H., \& Quaddus, M. (2016). Supply chain readiness, response and recovery for resilience. Supply Chain Management, 21(6), 709-731. https://doi.org/10.1108/SCM-122015-0463

10. Coombs, T. (2000). Designing Post-Crisis Messages: Lessons for Crisis Response Strategies. Review of Business, 37-41.

11. Coombs, W. (2007). Ongoing crisis communication: Planning, managing, and responding ( $2^{\text {nd }}$ ed.). Thousand Oaks, CA: Sage.
12. Crandall, W., Parnell, J A., \& Spillan, J. E. (2014). Crisis Management in the New Strategy Landscape ( $2^{\text {nd }}$ ed.). Los Angeles: Sage.

13. Dierdorf, S. (2019). Becoming Agile. Tiffany Taylor.

14. Ewel, J. (2011). Getting Started with Agile marketing [PowerPoint Slides]. Retrieved from www. agilemarketing.net/GettingStartedWithAgileMarketing.pdf

15. Félix, Á., Reinoso, N. G., \& Vera, R. (2020). Participatory diagnosis of the tourism sector in managing the crisis caused by the pandemic (COVID-19). Revista interamericana de ambiente y turismo, 16(1), 66-78. http://dx.doi.org/10.4067/s0718$235 \times 2020000100066$

16. Fink, S. (1996). Crisis management: Planning for the inevitable. New York: American Management Association.

17. Fryrear, A. (2018). Agile Marketing Journey Continues: State of Agile Marketing 2018. Agile Sherpas. Retrieved from https://www. agilesherpas.com/state-agile-marketing-2018/

18. Gligor, D. M., Esmark, C. L., \& Holcomb, M. C. (2015). Performance outcomes of supply chain agility: when should you be agile? Journal of Operations Management, 33-34(1), 7182. https://doi.org/10.1016/j. jom.2014.10.008

19. Gligor, D. M., Holcomb, M. C., \& Stank, T. P. (2013). A Multidisciplinary Approach to Supply Chain Agility: Conceptualization and Scale Development. Journal of Business Logistics, 34(2), 94-108. https:// doi.org/10.1111/jbl.12012

20. Golgeci, I., \& Gligor, D. M. (2017). The interplay between key marketing and supply chain management capabilities: the role of integrative mechanisms. Journal of Business \& Industrial Marketing, 32(3), 472-483. https://doi.org/10.1108/ JBIM-05-2016-0102

21. Guevara, G. (2020, March 17). Open letter to Governments from WTTC and the Travel \& Tourism sector. World Travel \& Tourism Council. Retrieved from https:// wttc.org/News-Article/Openletter-from-WTTC-to-Governments-from-WTTC-and-the-

Travel-Tourism-sector

22. Hair, J. F., Black, W. C., Babin, B. J., \& Anderson, R. E. (2010). Multivariate Data Analysis. Upper Saddle River, NJ: Prentice-Hall.

23. Heimicke, J., Kaiser, S., \& Albers, A. (2021). Agile product development: an analysis of acceptance and added value in practice. Procedia CIRP, 768773. Retrieved from https:// publikationen.bibliothek.kit. edu/1000134118

24. Hoisington, A. (2020, March 17). 5 Insights about how the COVID-19 pandemic will affect hotels. Hotel Management. Retrieved from www.hotelmanagement.net/own/ roundup-5-insights-about-howcovid-19-pandemic-will-affecthotels

25. Homburg, C., \& Pflesser, C. (2020). A Multiple-Layer Model of Market-Oriented Organizational Culture: Measurement Issues and Performance Outcomes. Journal of Marketing Research, 37(4), 449462. https://journals.sagepub.com/ doi/10.1509/jmkr.37.4.449.18786

26. Inversini, A., Pesonen, J., \& Buhalis, D. (2014). Agile marketing for tourism destinations. Proceedings of the Academy of Marketing Conference, 155. Bournemouth, United Kingdom.

27. Jabouri, S. (2011). The impact of leadership characteristics on the crisis management strategy A field study for a number of general directorates Ministry of Electricity/Iraq. The magazine of Economics \& Administration, 90, 194-220.

28. Jiang, Y., \& Wen, J. (2020). Effects of COVID-19 on hotel marketing and management: a perspective article. International Journal of Contemporary Hospitality Management, 32(8), 25632573. https://doi.org/10.1108/ IJCHM-03-2020-0237

29. Kalaignanam, K., Tuli, K. R., Kushwaha, T., Lee, L., \& Gal, 
D. (2021). Marketing Agility: The Concept, Antecedents, and a Research Agenda. Journal of Marketing, 85(1), 35-58. https:// journals.sagepub.com/doi/ abs/10.1177/0022242920952760

30. Karam, M. G. (2018). The Impact of Strategic Planning on Crisis Management Styles in the 5-Star Hotels. Journal of Hotel \& Business Management, 7(1). https://doi. org/10.4172/2169-0286.1000171

31. Kartik, K., Kapil, R., Tarun, K., Leonard, L., \& David, G. (2020). Marketing Agility: The Concept, Antecedents, and a Research Agenda. Journal of Marketing, 1-24. https://doi. org/10.1177/0022242920952760

32. Kim, Y. (2002). Understanding crisis management: Public relationship and crisis communication. Seoul, Korea: Book and Road.

33. Li, X., Goldsby, T. J., \& Holsapple, C. W. (2009). Supply chain agility: scale development. The International Journal of Logistics Management, 20(3), 408-424. https://doi. org/10.1108/09574090911002841

34. Malhotra, N. K. (2010). Marketing research, an applied orientation (6th ed.). Hoboken, NJ: Pearson.

35. Matthyssens, P., Pauwels, P., \& Vandenbempt, K. (2005). Strategic flexibility, rigidity and barriers to the development of absorptive capacity in business markets: themes and research perspectives. Industrial Marketing Management, 34(6), 547-554. https://doi.org/10.1016/j.indmarman.2005.03.004

36. Mazzocchi, M. (2008). Statistics for marketing and consumer research. London, UK: Sage.

37. Meyer, P. (2016). Agility Shift: Creating Agile and Effective Leaders, Teams, and Organizations. New York: Routledge.

38. Millar, C. M., Olaf, G., \& John, F. (2018). Management innovation in a VUCA World: Challenges and Recommendations. California Management Review, 61(1), 5-14. https://doi. org/10.1177/0008125618805111
39. Ministry of Tourism and Antuques. (2019). Tourism Statistics. Jordan.

40. Mitroff, I. I., Pearson, C. M., \& Harrington, L. K. (1996). The Essential Guide to Managing Corporate Crises: A step by step Handbook for Surviving Major Catastrophes. New York: Oxford Press.

41. Mitroff, I., \& Pearson, C. M. (1993). Crisis Management: A Diagnostic Guide for Improving your Organization's Crisis Preparedness. San Francisco, CA: Jossey-Bass Publishers.

42. Mitroff, I. I., Shrivastava, P., \& Udwadia, F. (1987). Effective Crisis Management. Academy of Management Executives, 1(3), 283-292.

43. Moi, L. (2019). Organizing for the digital world: a pathway towards the agile marketing capability (Unpublished Ph.D. thesis). Università degli Studi di Cagliari.

44. Moorman, C. (2020, March 30). Making the Most of Your Marketing Team During COVID-19. Forbes. Retrieved from https:// www.forbes.com/sites/christinemoorman/2020/03/30/ making-the-most-of-yourmarketing-team-during-covid$19 /$ ? $\mathrm{sh}=30 \mathrm{e} 936 \mathrm{ad} 2321$

45. Myers, K. (1993). Total contingency planning for disasters: Managing risk...minimizing loss... ensuring business continuity. New York: John Wiley.

46. Nemkova, E. (2017). The impact of agility on the market performance of born-global firms: an exploratory study of the 'Tech City' innovation cluster. Journal of Business Research, 80, 257265. https://doi.org/10.1016/j. jbusres.2017.04.017

47. O'Keeffe, A., Ozuem, W., \& Lancaster, G. (2016). Leadership marketing: an exploratory study. Journal of Strategic Marketing, 24(5), 418-443. https://doi.org/10.1080/096525 4X.2014.1001867

48. Osei, C., Amankwah-Amoah, J., Khan, Z., Omar, M., \& Gutu, M. (2019). Developing and deploying marketing agility in an emerging economy: the case of Blue Skies. International Marketing Review, 36(2), 190-212. https://doi. org/10.1108/IMR-12-2017-0261

49. Pauchant, T. C., \& Mitroff, I. I. (1992). Transforming the Crisis Prone Organization. San Francisco, CA: Jossey-Bass Publishers.

50. Pearson, C. M., \& Clair, J. A. (1998). Reframing Crisis Management. The Academy of Management Review, 23(1), 59-76. https://doi.org/10.2307/259099

51. Pearson, C. M., \& Mitroff, I. I. (1999). From crisis prone to crisis prepared: a framework for crisis management. Academy of Executive Management, 7(1), 48-59.

52. Prange, C., \& Heracleous, L. (2018). Agility X: How Organizations Thrive in Unpredictable Times. Cambridge: Cambridge University Press.

53. Rachmawati, A., Noermijati, Sumiati, \& Moko, W. (2019). The concept of network marketing agility and its implications. Proceedings of the 2019 International Conference on Organizational Innovation. Atlantis Press. https://dx.doi. org/10.2991/icoi-19.2019.31

54. Raouf, M., Elsabbagh, D., \& Wiebelt, M. (2020). Impact of COVID-19 on the Jordanian economy: Economic sectors, food systems, and households (MENA Policy Note 9). Washington, DC: International Food Policy Research Institute (IFPRI) https://doi.org/10.2499/ p15738coll2.134132

55. Richardson, B. (1994). Sociotechnical disasters: Profile and prevalence. Disaster Prevention \& Management, 3(4), 41-69. Retrieved from https://www.deepdyve.com/lp/emerald-publishing/ socio-technical-disasters-profileand-prevalence-bANgLgUyzS

56. Ritchie, B. W. (2004). Chaos, crises and disasters: a strategic approach to crisis management in the tourism industry. Tourism Management, 25(6), 669-683. Retrieved from https://www. 
academia.edu/290519/Chaos_Crises_and_Disasters_a_Strategic_Approach_to_Crisis_Management_In_the_Tourism_Industry

57. Ritchie, B. W., \& Jiang, Y. (2019). A review of research on tourism risk, crisis and disaster management: Launching the annals of tourism research curated collection on tourism risk, crisis and disaster management. Annals of Tourism Research, 79, 102812. https://doi. org/10.1016/j.annals.2019.102812

58. Saeed, O. (2020). The role of transformative leadership in activating crisis management dimensions in health institutions in Sudan. Journal of Research and Commercial Studies, 4(2), 94-112.

59. Smith, D. (1990). Beyond contingency planning: Towards a model of crisis management. Industrial Crisis Quarterly, 4(4), 263-275. https://doi. org/10.1177/108602669000400402

60. Sorrells, M. (2020, March 26). Data shows severe impact of coronavirus on global hospitality industry. PhocusWire. Retrieved June 20, 2021, from https://www. phocuswire.com/str-global-hoteldata-march-21-coronavirus

61. Tahmasebifard, H.,
Zangoueinezhad, A., \& Jafari, P. (2017). The Role of Entrepreneurial Orientation in Achieving Agility Capability. Journal of Applied Economics and Business Research, 7(2), 137-156.

62. Tachizawa, E. \& Gimenez, C. (2010). Supply flexibility strategies in Spanish firms: Results from a survey. International Journal of Production Economics, 124(1), 214-224. https:// doi.org/10.1016/j.ijpe.2009.11.020

63. The Economist. (2018, July 5). The fashion for agile management is spreading. Retrieved from https://www.economist.com/business/2018/07/05/the-fashion-foragile-management-is-spreading

64. The Institute for Crisis Management (ICM). (n.d.). What Defines a Crisis? Retrieved June 5, 2021, from https://crisisconsultant.com/

65. UNEP. (2008). Disaster Risk Management for Coastal Tourism Destinations Responding to Climate Change. A Practical Guide for Decision Makers. Washington: UNEP. Retrieved from https://wedocs.unep.org/ handle/20.500.11822/7806
66. Varelas, S., \& Apostolopoulo, N. (2020). The Implementation of Strategic Management in Greek Hospitality Businesses in Times of Crisis. Sustainability, 12(17), 7211. https://doi.org/10.3390/ su12177211

67. Vinodh, S. (2010). Improvement of Agility and Sustainability: A Case Study in and Indian Rotary Switches Manufacturing Organization. Journal of Cleaner Production, 18(10/11), 10151020. https://doi.org/10.1016/j. jclepro.2010.02.018

68. WTTC (World Travel \& Tourism Council). (n.d.). 30 years of WTTC. Retrieved April 8, 2021, from https://www.wttc.org/about/ media-centre/press-releases/ press-releases/2020/latest-research-from-wttc-shows-anincrease-in-jobs-at-risk-in-traveland-tourism/

69. Zhou, X., Li, N., Luo, Y., Liu, Y. Miao, F., Chen, T., Zhang, S., Cao, P., Li, X., Tian, K., Qiu, H-J. \& Hu, R. (2018). Emergence of African Swine Fever in China, 2018. Transboundary and Emerging Diseases, 65(6), 14821484. https://doi.org/10.1111/ tbed.12989 